\title{
Biological and Physicochemical Properties of Cowpea Severe Mosaic Comovirus Isolated from Soybean in the State of Paraná
}

\author{
Paula V. Bertacini ${ }^{1}$, Álvaro M.R. Almeida ${ }^{1 *}$, J. Albérsio A. Lima ${ }^{2}$ and Cesar M. Chagas ${ }^{3}$ \\ ${ }^{I}$ Embrapa Soja, Caixa Postal 231, 86001-970, Londrina, PR; ${ }^{2}$ Departamento de Fitossanidade, UFC, Fortaleza, \\ CE; ${ }^{3}$ Instituto Biológico de São Paulo.
}

\begin{abstract}
Soybean plants with symptoms of bud blight were growing close to cowpea with severe symptoms of mosaic associated with blisters in the leaves. A group of plants of both species were collected and used for etiological studies. This kind of symptom in soybeans was common in certain areas of the State of Paraná, induced by tobacco streak ilarvirus. Host range, serological reaction, particle morphology and size, protein and nucleic acid analysis, and transmission by beetles from species Cerotoma arcuata Oliv. showed that the virus involved was cowpea severe mosaic comovirus. This is the first report on the occurrence of this virus in soybean plants in the State of Paraná. Results using indirect ELISA showed that in cowpea the relative virus concentration was higher in green leaf areas than in chlorotic ones. Also, virus concentration, determined through indirect ELISA was much higher in plants kept at diurnal regime of $25^{\circ} \mathrm{C} \times 23^{\circ} \mathrm{C}(12 \times 12 \mathrm{~h})$ than at $30^{\circ} \mathrm{C} \times 28^{\circ} \mathrm{C}$.
\end{abstract}

Key words: soybean; cowpea severe mosaic comovirus; Indirect ELISA

\section{INTRODUCTION}

Soybean is the most important grain crop in Brazil and occupies an area of 12 million hectares. The yield average has increased along the years to $3,000 \mathrm{~kg} / \mathrm{ha}$ (Roessing \& Guedes, 1993). Despite the high yields, it is not unusual to find farmers claiming for losses caused by diseases such as soybean cyst nematode and stem canker (Mendes \& Dickson, 1992; Wrather et al., 1997).

Viruses have been also reported to cause damage to soybeans, and at least 13 viruses have been described naturally infecting soybean in the fields (Costa, 1977; Almeida, 1994). A symptom observed in soybean fields, called bud blight could be induced by several viruses (Costa, 1988). However, in the State of Paraná this symptom has been associated with the infection caused by tobacco streak ilarvirus (Costa \& Carvalho, 1961) and was responsible for severe losses to the farmers in the past (Almeida et al., 1995).

In Londrina, State of Paraná, soybean plants with bud blight were observed close to cowpea plants exhibiting severe mosaic and leaf distortion. Samples from both species were collected for etiological studies and the results showed that the same virus was responsible for the symptoms in both plants. The virus was identified as cowpea severe mosaic comovirus (CpSMV) with characteristics similar to those already described (Anjos \& Lin, 1980). CpSMV was first reported in Brazil (Oliveira, 1947). Later, the virus was also mentioned in Northeast and Central regions of Brazil (Costa et al., 1969; Lima \& Nelson, 1977; Cupertino et al., 1981; Rios \& Neves, 1982). It has three separate components in sucrose gradient, with 58, 98 and $118 \mathrm{~S}$ values for the top, middle and botton component, respectively. It has a bipartite genome and is transmitted by beetles from the genus Cerotoma (Jager, 1979). Serological evaluations of CpSMV isolates from different Brazilian regions have shown the occurrence of four serotypes (Lin et al., 1980).

This study was done to identify and characterize the isolate of CpSMV as well as to evaluate its

\footnotetext{
* Author for correspondence
} 
biological and physicochemical properties. Additionally it was evaluated the relative virus concentration between green and chlorotic leaf areas as well as the virus concentration in cowpea plants kept at two different regimes of temperature, trying to simulate temperature effects, commonly found in Northern and Southern regions of Brazil.

\section{MATERIAL AND METHODS}

Virus isolation and maintenance. Soybean and cowpea leaves showing symptoms of systemic necrosis and severe mosaic, respectivelly, were collected from the field and used as source of inoculum. Leaves were ground in a sterile frozen mortar with sodium phosphate buffer $0.01 \mathrm{M}, \mathrm{pH} 7.0(1: 5 \mathrm{w} / \mathrm{v})$. The extract was applied to the soybean and cowpea leaves previously dusted with charcoal. Inoculated leaves were lightly washed and the plants were kept in greenhouse.

Transmission trials. Aphids (Myzus persicae Sulz.) were reared in raddish (Raphanus sativus L.). After starvation for $1 \mathrm{~h}$, insects were transferred to systemically infected leaves of cowpea and allowed to probe for $5 \mathrm{~min}$. Five aphids per plant were transferred to healthy soybean cv. Santa Rosa and cowpea cv. Blackeye where they stayed for $24 \mathrm{~h}$. Plants were then sprayed with malathion. Beetles (Cerotoma arcuata Oliv.) raised on healthy french beans (Phaseolus vulgaris L.) cv. Tibagi, were transferred to cowpea plants systemically infected and allowed to feed for $72 \mathrm{~h}$. Insects were then transferred to soybean and cowpea plants, kept inside cages for $72 \mathrm{~h}$ and killed with malathion. Five insects per plant were used. Plants were scored for symptoms 2-3 weeks later.

Electron microscopy. Virus particles were visualized through a leaf dip method (Kitajima, 1965). Additionaly, purified preparation was observed after negative staining using 2\% uranyl acetate.

Purification. Cowpea leaves cv. Blackeye, systemically infected were harvested approximately three weeks after inoculation and ground in blender with sodium phosphate buffer $0.1 \mathrm{M}, \mathrm{pH}$ 7.2, $0.01 \mathrm{M}$ EDTA and sodium sulfite $1 \%(1: 2 \mathrm{w} / \mathrm{v})$. The emulsion was mixed with butanol $(8 \%)$, agitated for $20 \mathrm{~min}$ at $4{ }^{\circ} \mathrm{C}$ and stored for another $10 \mathrm{~min}$. The slurry was centrifuged at $10,000 \mathrm{x} \mathrm{g}$ for $10 \mathrm{~min}$. Polyethylene glycol (molecular weight 6,000) was added to the supernatant to a final concentration of $8 \%$, stirred for $1 \mathrm{~h}$ at $4^{\circ} \mathrm{C}$. Precipitate was recovered after centrifugation at $12,000 \mathrm{x}$ g for $10 \mathrm{~min}$ and resuspended in 1/10 initial volume with $0.1 \mathrm{M}$ sodium phosphate buffer, $\mathrm{pH} 7.2$, stirring overnight at $4^{\circ} \mathrm{C}$. Solution was clarified by centrifugation at $10,000 \mathrm{x} \mathrm{g}$ for 10 minutes and the supernatant was centrifuged at $154,000 \times \mathrm{g}$ for $2 \mathrm{~h}$. Pellets were ressuspended in a total volume of $2.4 \mathrm{ml}$ sodium phosphate buffer $0.01 \mathrm{M}, \mathrm{pH}$ 7.2. Virus preparation was layered on frozen solution of sucrose (20\%) (Baxter-Gabbard, 1972; Davis \& Pearson, 1978) and centrifuged at $134,000 \mathrm{x} \mathrm{g}$ for $2 \mathrm{~h}$. Tubes were scanned in ISCO fractionator, model UA-5, monitoring UV absorbance at $254 \mathrm{~nm}$. Peaks were collected, diluted $3 \mathrm{x}$ with sodium phosphate buffer 0.01 $\mathrm{M}, \mathrm{pH} 7.2$ and again centrifuged at $134,000 \mathrm{x} \mathrm{g}$ for $2.5 \mathrm{~h}$. Pellets were finally resuspended in 0.3 $\mathrm{ml}$ of the same buffer and subjected to $8,000 \mathrm{x} \mathrm{g}$ for $10 \mathrm{~min}$. Supernatant was used for spectrophotometry.

Protein analysis. The molecular weight of viral coat protein was estimated by electrophoresis in sodium dodecyl sulfate (SDS) polycarilamide gels consisting of a $3.75 \%$ stacking gel and $12.5 \%$ resolving gel (Laemmli, 1970). Protein was dissociated from its RNA by boiling the virions for $3 \mathrm{~min}$ in $0.125 \mathrm{M}$ Tris - $\mathrm{HCl}$ buffer, $\mathrm{pH} \quad 8.3$, containing $1 \%$ SDS, $1 \% \quad 2-$ mercaptoethanol and $4 \mathrm{M}$ urea. Mobility of the protein molecular markers (Pharmacia LMW calibration kit) were used for estimating the viral protein molecular weight. Gels were stained with coomassie briliant blue R250 (Sigma, St. Louis, USA).

Serology. Antiserum was prepared using New Zeland rabbits in which it was given three intramuscular injections at a week's interval, receiving a total of $3 \mathrm{mg}$ of virus. Bleeding was carried out at 10 days interval after the final 
injection. The first injection was prepared with complete Freund's adjuvant and the second and third were prepared by using incomplete adjuvant. Other antisera against CpSMV were provided by Dr. J.A.A.Lima (Universidade Federal do Ceará) and Dr. P.S.T.Brioso (Universidade Federal Rural do Rio de Janeiro). Double diffusion tests were performed in $0.8 \%$ agarose containing $0.02 \%$ sodium azide in distilled water by using patterns of six wells around a central well. Evaluations were recorded $24 \mathrm{~h}$ after incubation of the plates in humid chamber at room temperature.

Host range tests. At least eight plants from different botanical families were mechanically inoculated as described before using inoculum prepared from cowpea leaves systemically infected, homogenized in $0.01 \mathrm{M}$ sodium phosphate buffer, $\mathrm{pH}$ 7.0. Symptoms were recorded 2-3 weeks after inoculation.

Virus content. The relative virus content was measured three weeks after inoculation by indirect ELISA (Koenig, 1981) using samples from green and chlorotic areas in cowpea leaves showing symptoms of mosaic. The experimental design for this experiment was completely randomized with three replications. Each pot containing three plants was considered one replication. Three weeks after inoculation the primary leaf and the middle leaflet from the second, third, fourth and fifth trifoliolate leaves of each plant were collected. Leaves from the same position and from plants in the same pot were stacked and cut with a cork borer (3.4 $\mathrm{cm}^{2}$ ). Sample disks were ground on coating buffer ( $\mathrm{pH} 9.6)(1: 2 \mathrm{w} / \mathrm{v})$, diluted and directly coated into the microtitre plates $(100 \mu \mathrm{l} /$ well $)$ overnight at $4{ }^{0} \mathrm{C}$. Optimum working dilution was 1:300 for the rabbit IgG and 1:50 for the plant extract. Alkaline phosphatase conjugate to goat and anti-rabbit IgG (Sigma, USA) was diluted 3,000-fold. Absorbance was recorded at $405 \mathrm{~nm}, 30 \mathrm{~min}$ after adding the substrate pnitrophenyl phosphate (Sigma, USA). The reaction was stopped with $3 \mathrm{~N} \mathrm{NaOH}$. Mean absorbances were determined from triplicate wells. Between each incubation step, wells were washed with PBS. A sample was considered positive only when it had two times the absorbance values of the control.
Temperature effect on virus content. Mechanically infected plants of cowpea cv. Pitiúba were submitted to two different regimes of temperature $\left(25^{\circ} \mathrm{C} \times 23^{\circ} \mathrm{C} ; 30^{\circ} \mathrm{C} \times 28^{\circ} \mathrm{C}\right)$ in $12 \times 12 \mathrm{~h}$ of light and darkness, respectivelly. At $7,15,22,29$ and 35 days after inoculation (DAI), five plants of each treatment were collected and the leaves used for indexing relative virus content by indirect ELISA.

\section{RESULTS AND DISCUSSION}

After mechanical inoculation the virus was able to infect several plant species (Table 1). All soybean cultivars tested showed severe necrosis and bud blight 10-12 DAI. Cowpea plants cv. Pitiúba showed severe mosaic associated to blisters while cv. Blackeye exhibited systemic necrosis. Chenopodium amaranticolor and $C$. quinoa exhibited small, circular, chlorotic local lesions about eight days after inoculation. These lesions later became necrotic. The virus was not transmitted through Myzus persicae Sulz. but it was through Cerotoma arcuata Oliv. Seven plants out of ten showed infection.

Following sucrose density gradient centrifugation, purified preparation showed three ultraviolet absorbing bands (Fig. 1). Average yields of purified virus ranged from 5-9 $\mathrm{mg} / 100 \mathrm{~g}$ of infected tissue, calculated from extinction coefficient of 10.0 (Van Kammen, 1971). Middle and botton components were observed in large amounts. Purified virus showed an ultraviolet absorption spectrum typical of nucleoprotein with maximum absorption at 260-262 $\mathrm{nm}$ and minimum at 240$242 \mathrm{~nm}$. The $\mathrm{A}_{260} / \mathrm{A}_{280}$ ratio for unfractioned virus was in the range of 1.50 and 1.68 with a mean of 1.53 for six preparations (values not corrected for light scattering). Analysis of CpSMV denatured proteins resolved as two separate bands under reducing conditions showing a molecular weight of $42.1 \mathrm{KDa}$ and 18.2 KDa (Fig 1C) which are in accordance to 
Table I. Reaction of several botanical species mechanicaly infected by cowpea severe mosaic comovirus.

\begin{tabular}{|c|c|}
\hline Species & Reaction \\
\hline $\begin{array}{l}\text { Fam. Leguminosae } \\
\text { Glycine max (L.) Merr. } \\
\text { cv. Davis } \\
\text { cv. Santa Rosa* } \\
\text { Phaseolus vulgaris L. } \\
\text { cv. Carioca* } \\
\text { cv. Jalo* } \\
\text { cv. Manteiga* } \\
\text { cv. Rosinha* } \\
\text { cv. Tibagi* } \\
\text { Vigna unguiculata } \text { (L.) Walp. } \\
\text { Cv. Black eye } \\
\text { Crotalaria spectabilis Roth. } \\
\text { Crotalaria juncea L. } \\
\text { Crotalaria striata Dc. } \\
\text { Crotalaria mucronata Desv. }\end{array}$ & $\begin{array}{c}\mathrm{M} / \mathrm{E} \\
\mathrm{SM} \\
\\
\mathrm{NS} \\
\mathrm{SM} / \mathrm{Y} \\
\mathrm{M} / \mathrm{CLL} \\
\mathrm{M} / \mathrm{CLL} \\
\mathrm{NS} \\
\mathrm{SM} / \mathrm{CLL} / \mathrm{SN} \\
\mathrm{M} / \mathrm{CLL} \\
\mathrm{M} / \mathrm{CLL} \\
\mathrm{NS} \\
\mathrm{NS}\end{array}$ \\
\hline $\begin{array}{l}\text { Fam. Solanaceae } \\
\text { Lycopersicum esculentum Mill. } \\
\text { Datura stramonium L. } \\
\text { Nicotiana tabacum L. }\end{array}$ & $\begin{array}{l}\text { NS } \\
\text { NS } \\
\text { NS }\end{array}$ \\
\hline $\begin{array}{l}\text { Fam. Chenopodiaceae } \\
\text { Chenopodium amaranticolor Coste \& Reyn } \\
\text { Chenopodium quinoa Willd } \\
\text { Chenopodium murale L. }\end{array}$ & $\begin{array}{l}\text { CLL/NLL } \\
\text { CCL } \\
\text { LLC }\end{array}$ \\
\hline $\begin{array}{l}\text { Fam. Compositae } \\
\text { Bidens pilosa } \mathrm{L} \text {. } \\
\text { Gomphrena globosa }\end{array}$ & $\begin{array}{c}\mathrm{NS} \\
\mathrm{M} / \mathrm{CLL}\end{array}$ \\
\hline $\begin{array}{l}\text { Fam. Cucurbitaceae } \\
\text { Cucurbita pepo L. }\end{array}$ & NS \\
\hline
\end{tabular}

NS: no syptoms; M:mosaic; SM: severe mosaic; CLL: chlorotic local lesion; NLL: necrotic local lesion; Y: yellowing; E: epinasty; SN: systemic necrosis.

* Plants indexed in C. amaranticolor.

previous reports (Jager, 1979; Brioso et al., 1996). Good agreements were observed between various estimates which suggested that the protein did not behave anomalously and bound the usual $1.4 \mathrm{~g}$ of SDS/g of protein (Pitt-Rivers \& Impiombato, 1969). In the electron microscope, viral preparation contained isometric particles measuring $29 \mathrm{~nm}$ in diameter (Fig. 1B).

Sap from infected cowpea reacted strongly with antisera of CpSMV-Pi, CpSMV-Ce, and
CpSMV-RJ. Antiserum produced against this isolate showed a titer of $1 / 512$ and reacted with healthy tissue at a titer less than $1 / 8$ dilution.

The effect of temperature on plant virus replication or translocation has been mentioned by Dawson et al. (1975). Data shown in this paper confirmed those effects but in a different order. Instead of an increase in relative virus concentration a decrease was detected, meaning that at low temperatures the virus 


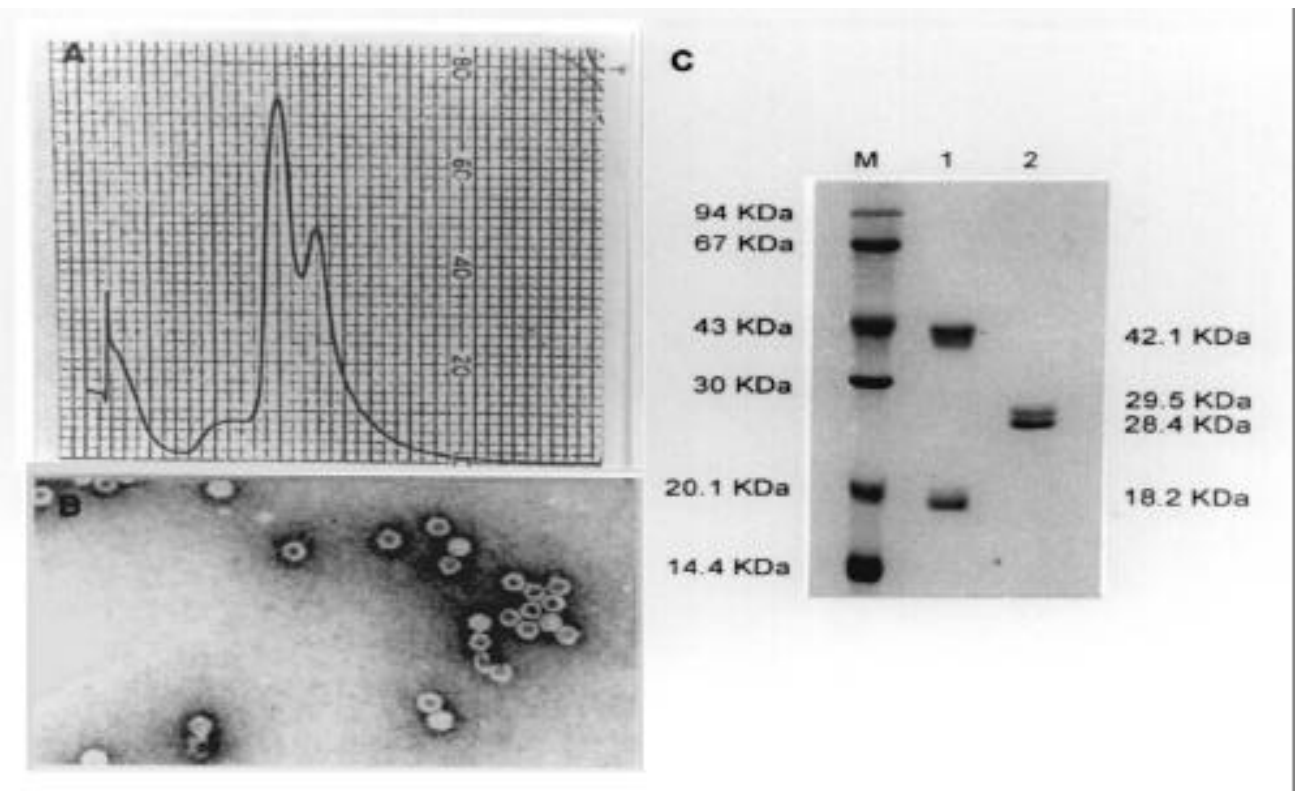

Figure 1. (A)Ultraviolet absorbance profiles of cowpea severe mosaic virus purified from soybean by rate zonal sucrose gradient (20\% frozen sucrose); (B)Electron microscopy of CpSMV showing particles $29 \mathrm{~nm}$ diameter; (C)Molecular weight of the capsid protein from cowpea severe mosaic virus; Lane $\mathrm{M}$ (markers): Fosforilase b, $94 \mathrm{Kda}$; bovine serum albumin $67 \mathrm{KDa}$; egg albumin, $43 \mathrm{KDa}$; carbonic anydrase, $30 \mathrm{KDa}$; trypsinogen, $20 \mathrm{Kda}$ and lactalbumin, $14.4 \mathrm{KDa}$; Lane 1 = cowpea severe mosaic virus coat protein; Lane $2=$ Tobacco streak virus coat protein .
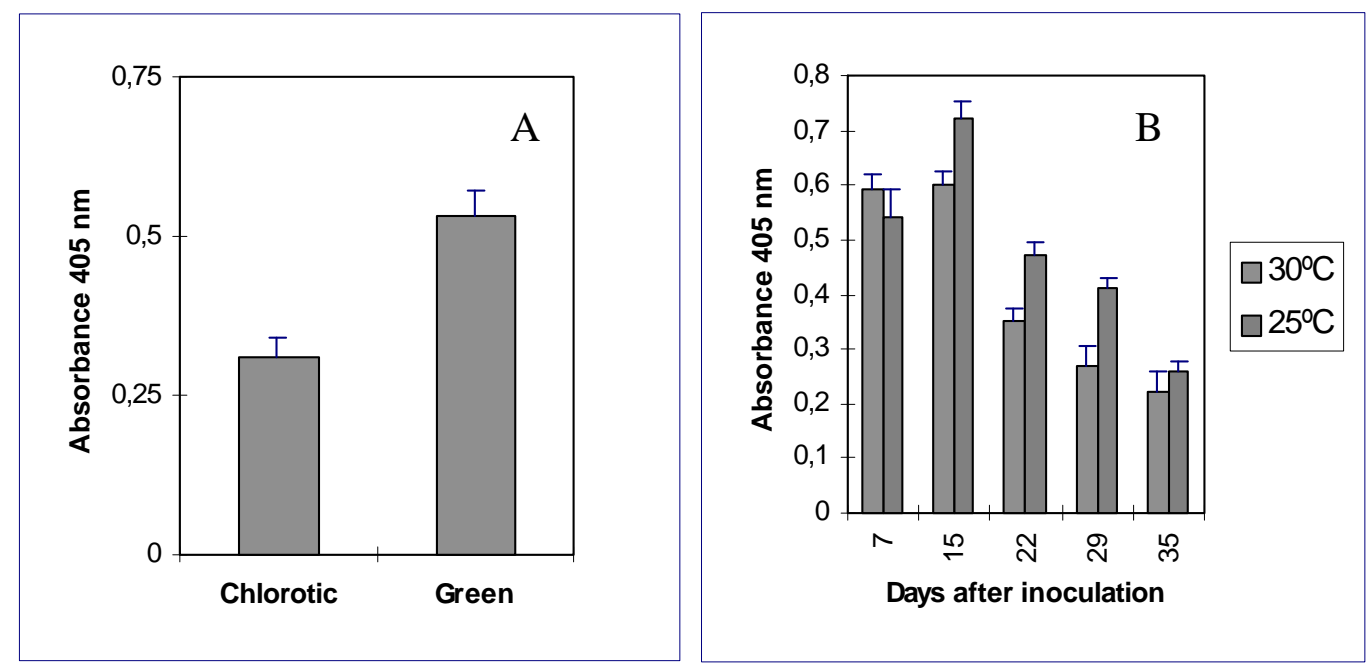

Figure 2. A: Relative content of cowpea severe mosaic virus in leaf samples from chlorotic and green areas, measured by indirect ELISA. Error bars correspond to standard error of the means; B: Relative content of cowpea severe mosaic virus, determined by indirect ELISA in cowpea leaves at 7, 15, 22, 29 and 35 days after mechanical inoculation. Plants were maintained at two regimes of temperature $\left(30 \times 28^{\circ} \mathrm{C} \mathrm{e}\right.$ $25 \times 23^{\circ} \mathrm{C}$ ). Error bars correspond to standard error of the means. 
replicated better than at $30^{\circ} \mathrm{C}$. Probably $30^{\circ} \mathrm{C}$ was not the ideal temperature for replication of this isolate. Virus concentration tended also to decrease along the days after inoculation. It was not clear if this fact was only due to the chlorosis and systemic necrosis symptoms observed in cowpea leaves or was due to any other fact not identified in this work. Although evaluating biochemical or phisiological differences between green and chlorotic areas was not na objective previously targetted for this study, it was interesting to observe that chlorotic areas had less virus, suggesting that an interference could be associated with this event. An additional cytological study may confirm viral effect on cell organels that could explain this finding.

Soybean bud blight induced by tobacco streak ilarvirus was a symptom usually found in the past among soybean fields located at Southern States of Brazil (Costa, 1977; Almeida et al., 1995). Several viruses can infect soybean and induce symptoms of bud blight (Costa, 1988). One of them is cowpea severe mosaic comovirus (CpSMV). The occurrence of CpSMV naturally infecting soybeans in Paraná is a new event. This symptom was first described in soybean fields in Brasília, Federal District (Anjos and Lin, 1980). Results obtained in this study such as particle size and morphology, coat protein size, nucleic acid profile, particle sedimentation profile in sucrose gradient, host range and serological relationships confirmed the natural occurrence of CpSMV in soybeans, grown in the State of Paraná. A previous report of this study was showed that this isolate was serologically identical to others identified in Northern states (Bertacini et al.,1994).

Because of the severity of the disease in soybeans, this virus poses a serious threat to this crop in traditional areas, as well as to new areas in Northern States where soybean is expanding steadly. So far, no genetical source of resistance has been identified in the soybean germplasm bank of Embrapa Soja (Almeida, 1996). Cowpea is a traditional and important source of protein for human nutrition in Northeastern States, where genetical resistance against CpSMV has been used efficiently. However, the introduction of soybeans in that area may be threatened by this virus. Moreover, very few epidemiological parameters associated to virus spreading and persistence in the field are well understood in this crop.

This paper describes etiological studies related to the the occurrence of soybean bud blight caused by CpSMV and constitutes the first occurrence of this disease in soybeans grown in the State of Paraná.

\section{ACKNOWLEDGMENTS}

We are grateful to L.C. Benato and N. Valentin for technical help; to the editorial committee of Embrapa Soja for critical review of the manuscript. Also we are thankful to $\mathrm{CNPq}$ for funding part of this research and providing a fellowship to P.V. Bertacini.

\section{REFERENCES}

Almeida, A.M.R. Caracterização, epidemiologia e controle de viroses da soja: caracterização do banco ativo de germoplasma em relação às principais viroses. In: Resultados de Pesquisa da Embrapa Soja, 1996. pp.97 100, 1996.

Almeida, A.M.R. Virus diseases. In: Tropical soybean: improvement and production. Ed. FAO. 1994. 254 pp.

Almeida, A.M.R.; Bergamin Filho, A.; Amorin, L.; Salomons, F.; Cerigatti, A.; Corso,I. O virus da queima do broto da soja no Brasil: etiologia, epidemiologia e controle. Documentos Embrapa No. 85. 1995. 33 p.

Anjos, J.R.N.; Lin, M.T. Queima do broto em soja causada por um membro do serotipo I do vírus do mosaico severo do caupi serogrupo Arkansas. Fitopatol. bras. 5: 382-383, 1980.

Baxter-Gabbard, K.L. A simple method for the large scale preparation of sucrose gradients. FEBS Letter, 20:117-119, 1972.

Bertacini, P.V.; Almeida, A.M.R.; Chagas, C.M.; Lima, J.A.A. Ocorrência natural do vÍrus do mosaico severo do caupi, infectando soja e caupi no estado do Paraná. Fitopatol. bras. 19:271, 1994. 
Brioso, P.S.T.; Duque, F.F.; Sayão, F.A.D.; Louro, R.P.; Kitajima, E.W.; OLIVEIRA, D.E. Vírus do mosaico severo do caupi infecção natural em mungo verde, Vigna radiata. Fitopatol. bras. 19:420-429, 1996.

Costa, A.S.; Carvalho, A.M.B. Studies on Brazilian tobacco streak. Phytopathologische Z. 42: 113-138, 1961.

Costa, A.S.; Oliveira, A.R.; Kitajima, E.W.; Matsukura, S. Ocorrência do mosaico do feijão macassar em São Paulo. Revista da Sociedade Brasileira de Fitopatologia 3:5657, 1969.

Costa, A.S. Investigações sobre moléstias da soja no estado de Sao Paulo. Summa Phytopathologica 3:3-30, 1977.

Costa, A.S. Queima do broto, sintoma produzido em soja por várias combinações vírusvariedade. Fitopatol. bras. 13: 180-182, 1988.

Cupertino, F.P.; Costa, C.L.; Lin, M.T.; Kitajima, E.W. Infecção natural do feijoeiro pelo vírus do mosaico do caupi no CentroOeste do Brasil. Fitopatol. bras. 7: 39, 1981.

Davis, P.B.; Pearson, C.K. Characterization of density gradients prepared by freezing and thawing a sucrose solution. Anal. Biochem. 91:343-349, 1978.

Dawson, W.O.; Schlegel, D.E.; Lung, M.C.Y. Synthesis of tobacco mosaic virus in intact tobacco leaves systemically inoculated by differential temperature treatment. Virology 65:565-573, 1975.

Jager, C.P. Cowpea severe mosaic virus. C.M.I./A.A.B. Descriptions of plant viruses. $\mathrm{N}^{\circ} 209,1979$.

Kitajima, E.W. Electron microscopy of vira cabeça virus within the host cell. Virology 26:89-99, 1965.

Koenig, R. Indirect ELISA methods for the broad specificity detection of plant viruses. $J$. Gen. Virol., 55: 53-62, 1981.

Laemmli, U.K. Cleavage of structural proteins during the assembly of the head of bacteriophage T4. Nature 227: 1018-1020, 1970.

Lima, J.A.A.; Nelson, M.R. Etiology and epidemniology of mosaic of cowpea in Ceará, Brazil. Plant Dis. Reptr. 61:864-867, 1977.
Lima, R.C.A.; Lima, J.A.A.; Marques, M.L.; Almeida, A.M.R. Variabilidade biológica entre estirpes do virus do mosaico severo do caupi sorologicamente idênticas. Fitopatol. bras. 19: 329, 1994.

Lin, M.T.; Anjos, J.R.N.; Rios, G.P. Agrupamento serológico de 14 isolados do "cowpea mosaic virus - Arkansas group" obtidos no Brasil central. Fitopatol. bras. 5:418-419, 1980.

Mendes, M.L.; Dickson, D.W. Heterodera glycines found on soybean in Brazil. $J$. Nematol. 24:4, 1992.

Oliveira, M.A. Contribuição ao estudo dos vírus causadores de mosaico dos feijões macassar (Vigna spp). Pelotas, Instituto Agronômico do Sul, 1947. 15p. (IAS. Boletim Técnico, 1), 1974.

Rios, G.P.; Neves, B.P. Resistência de linhagens e cultivares de caupi (Vigna unguiculata)ao vírus do mosaico severo (VMCS). Fitopatol. bras. 7:175-184, 1982.

Roessing, A.C.; Guedes, L.C.A. Aspectos econômicos do complexo soja: sua participação na economia brasileira e evolução na região do Brasil Central. In: Cultura da soja nos cerrados. Ed. N.E. Arantes e P.I. de Mello de Souza. 1993. pp.169.

Pitt-Rivers, R.; Impiombato, A.F.S. The binding of sodium dodecyl sulphate to various proteins. Biochem. J. 109: 825 - 830, 1969.

Van Kammen, A. Cowpea mosaic virus. C.M.I./A.A.B. Descriptions of plant viruses. $\mathrm{N}^{\mathrm{o}}$ 47, 1971.

Wrather, J.A.; Anderson, T.R.; Arsyad, D.M.; Gai, J.; Plopper, L.D.; Porta-Puglia, A.; Ram, H.H.; Yorinori, J.T. Soybean disease loss estimates for the top ten producing countries during 1994. Plant Dis. 81: 107-110, 1997.

Received: May 26, 1998; Revised: June 30, 1998; Accepted: November 13, 1998. 
